ScIDice

\section{Knowledge, Attitude and Practice Survey on Restoring Endodontically Treated Teeth Among the Specialists and General Practitioners}

Swathi UB ${ }^{1}$, Sindhu Ramesh ${ }^{2 *}$, S. Pradeep ${ }^{3}$

${ }^{1}$ Department of Conservative Dentistry and Endodontics, Saveetha Dental College and Hospital, Saveetha Institute of Medical and Technical Sciences, Saveetha University, Chennai, India.

${ }^{2}$ Professor, Department of Conservative Dentistry and Endodontics, Saveetha Dental College and Hospital, Saveetha Institute of Medical and Technical Sciences, Saveetha University, Chennai, India.

${ }^{3}$ Reader, Department of Conservative Dentistry and Endodontics, Saveetha Dental College and Hospital, Saveetha Institute of Medical and Technical Sciences, Saveetha University, Chennai, India.

Abstract

Introduction: The success of endodontically treated teeth mainly relies upon meticulous planning before initiating the root canal treatment. A post is placed in the root canal of a tooth when additional retention is needed to retain the core and should provide this support to the core without increasing the risk of root fracture.

Aim: The aim of this survey was to determine the awareness, current approaches, and techniques used in the restoration of endodontically treated teeth among general dentists,post graduates and endodontists.

Methodology: A descriptive questionnaire survey was conducted among 399 participants regarding restoration of endodontically treated teeth,in the month of August to September 2019. Out of 420 distributed questionnaires, 399 participants responded to the questionnaire.Data were analysed by using Statistical Package for Social Sciences (SPSS), Chi -Square Test was used to check the association based on the responses.

Results: The questionnaire was circulated among 420 dentists and 399 responded. It gives a response rate of $95 \%$.Since the p-value is significant there is an association between most of the groups and variables in this study. The Chi-square test results showed that there was a significant impact of most of the variables on restoring endodontically treated teeth among endodontists, concluding that endodontists have more knowledge with regard to restoring endodontically treated teeth $(\mathrm{p}<0.05)$. Conclusion: This survey shows thorough knowledge and awareness among postgraduates and endodontists, about restoring endodontically treated teeth and its management, and inadequate knowledge among general dentists.

Keywords: Endodontically Treated Teeth; KAP Survey; Practitioners; Root Canal Treated Teeth.

\section{Introduction}

The main outcome of endodontic therapy is to restore normal function, occlusion of the tooth and to maintain stability in the dental arch [1]. Teeth that were considered not restorable and extracted before can be retained now due to the predictable clinical success rate of endodontic therapy of more than 95\% [2-4]. The restoration of endodontically treated teeth encounter problems due to loss of tooth structure by caries, trauma, fracture, previous restoration, and Endodontic therapy, all of these decrease the fracture resistance of the tooth [5-8].
The strength of the endodontically treated teeth depend on the bulk of the remaining dentin. Root canal treated teeth with an intact coronal structure have good prognosis [9]. Studies have reported that the main cause of endodontic treatment failure is because of the failure of the restoration failure rather than failure due to endodontic treatment itself. The final restoration of the root canal treated teeth play an important role. Improper restoration after root canal treatment contributes to one of the reasons for tooth extraction $[10,11]$.

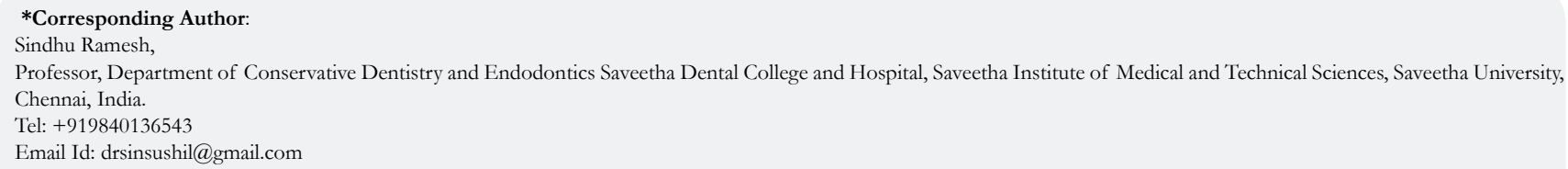

Citation: Swathi UB, Sindhu Ramesh, S. Pradeep. Knowledge, Attitude and Practice Survey on Restoring Endodontically Treated Teeth Among the Specialists and General Practitioners. Int J Dentistry Oral Sci. 2021;08(02):1724-1732. doi: http://dx.doi.org/10.19070/2377-8075-21000341

Copyright: Sindhu Ramesh 2021 . This is an open-access article distributed under the terms of the Creative Commons Attribution License, which permits unrestricted use, distribution and reproduction in any medium, provided the original author and source are credited. 
The different parameters that affect the prognosis of root canal treated teeth are amount of tooth structure that is lost, periapical status, position of the tooth, occlusal contacts, number of adjacent teeth, remaining coronal, root dentin, degradation of the collagen, final restoration, type of post and core material used and presence of a ferrule preparation in some cases [12-20].

Restoration of endodontically treated teeth should be assessed for occlusal function, restorability, periodontal status, biological width and crown to root ratio before initiating root canal therapy. All these factors should be considered in the treatment plan of endodontically treated teeth [21].

Amalgam and composite resin are the commonly used core foundations of root canal treated teeth as they are superior to glass ionomer cement [22]. Traditionally to retain the core in a tooth badly broken-down, a post is inserted into the root canal system which is further followed by a full-coverage crown to protect the tooth from fracture [23]. The main role of post-placement is to retain the core foundation and not reinforce an endodontically treated tooth [24]. Some studies have reported that the stress produced during the post space preparation and subsequent insertion has an impact on the increase in the risk of root fracture.

The literature reveals that post should be used only when there is not enough tooth structure to brace the core restoration $[25,26]$. The most important factor in reducing the risk of root fracture is the preservation of dentin as much as possible [27]. Coronal microleakage is another major cause of endodontic treatment failure, well-sealed temporary and permanent coronal restoration is another important factor for the clinical success of endodontic therapy [28].

The present study aimed to determine the awareness, current approaches, and techniques used in the restoration of endodontically treated teeth among general dentists, post graduates and endodontists.

\section{Materials And Methods}

This survey was conducted in the month of August to September 2019 among general dentists,post graduates and endodontists. Responses were received from 390 participants out of 420 which consisted of $71 \%$ males and $28 \%$ females. $93 \%$ of the participants belonged to the age group of 20-30 years. Individual survey forms were given for each practitioner and the responses were recorded.

An online survey was done with the structured questionnaire based on knowledge, attitude, practice survey among general dentists,post graduates and endodontists. about restoration of endodontically treated teeth and its management and it was distributed via electronic media. The questionnaire had 25 questions in which 4 questions included basic demographic data, 7 questions based on knowledge, 7 based on attitude, 7 questions based on practice were created. The participants were general dentists,post graduates and endodontists. A snowball sampling was followed for this study. The questionnaires were distributed via electronic media and responses were collected. All the participants were allowed to choose one of the given three to four choices for each item in the questionnaire. 399 responses were assessed. The ad- vantages of online surveys are easy collection of data,cost effective and the disadvantage is repeated answers and incomplete answers. Then, it was assessed whether knowledge, attitude, practice were sufficient about restoration of endodontically treated teeth.

\section{Ethical Approval}

Ethical permission and approval for the project was obtained from the Institutional Review Board of Saveetha Institute of Medical and Technical Sciences, Chennai, India [SDC/SIHEC/2020/ DATA/0619-0320].

\section{Eligibility Criteria}

Data Collection: This cross sectional survey was conducted during August to September 2019. The questionnaire was shared online via google forms and responses were obtained from 399 participants. The data for 25 questions was compiled and represented in a chart obtained from the google forms.

Sample Size: Total number of online questionnaires shared was 420. Out of which 21 did not take up the survey and were incomplete forms which were excluded from the study. Hence, the total number of the participants were 399.

\section{Statistical Analysis}

After data entry in the Excel sheet,SPSS software was used to analyze the data. The descriptive statistics were used to determine the frequencies and percentage of the responses given by the participants. Analysis was performed to find the correlation between KAP and their application in clinical situations. Chi Square test was performed. The results are obtained in bar diagrams.

\section{Results And Discussion}

The response rate of the participants in the present survey was satisfactory. Majority of the participants had good knowledge $(65 \%)$, attitude $(78.30 \%)$ and practice $(73.72 \%)$ regarding restoration of endodontically treated teeth. The questionnaire was circulated among 420 dentists and 399 responded. It gives a response rate of $95 \%$. A snowball sampling was followed for this study. All the participants were allowed to choose one of the given three to four choices for each item in the questionnaire. Lack of awareness of restoring endodontically treated teeth was found among the general practitioners in comparison to endodontists and post graduates. Since the p-value is significant there is an association between most of the groups and variables in this study.The Chisquare test results showed that there was a significant impact of most of the variables on restoring endodontically treated teeth among endodontists, concluding that endodontists have more knowledge with regard to restoring endodontically treated teeth $(p<0.05)$.Results of the study were represented in the form of graphs and tables.(Table 1,2) (Figure 1-10)

Surveys can serve as one of the important tools for understanding treatment approaches of clinicians towards Endodontically treated teeth [29-33]. More than half of the participants agreed that a post-placement depends on the remaining tooth structure while more than one third agreed to the placement of a post sometimes. The results were similar to the findings in the study done in 
Table 1. Showing distribution of cases which were included for the study based on Age, Gender and qualification.

\begin{tabular}{|c|c|c|c|}
\hline $\begin{array}{c}\text { Demographic } \\
\text { Variables }\end{array}$ & Categories & $\begin{array}{c}\text { No of } \\
\text { Respondents }\end{array}$ & Percentage \\
\hline \multirow{3}{*}{ Gender } & Female & 285 & $71.42 \%$ \\
\cline { 2 - 4 } & Male & 115 & $28.80 \%$ \\
\hline \multirow{4}{*}{ Age (years) } & $20-30$ years & 375 & $93.90 \%$ \\
\cline { 2 - 4 } & $31-40$ years & 16 & $4.01 \%$ \\
\cline { 2 - 4 } & 41-50 years & 5 & $1.25 \%$ \\
\cline { 2 - 4 } & $>50$ years & 3 & $0.75 \%$ \\
\hline \multirow{3}{*}{ Qualification } & Postgraduates & 134 & $33.60 \%$ \\
\cline { 2 - 4 } & Endodontist & 150 & $37.60 \%$ \\
\cline { 2 - 4 } & General practitioner & 115 & $28.80 \%$ \\
\hline
\end{tabular}

Table 2. Showing Questionnaire and the Responses.

\begin{tabular}{|c|c|c|c|}
\hline Question & Options & Number & Percentage \\
\hline $\begin{array}{l}\text { 1.What is the most appropri- } \\
\text { ate length of the post? }\end{array}$ & $\begin{array}{c}1 / 2 \text { length of root canal } \\
1 / 3 \text { length of root canal } \\
2 / 3 \text { length of root canal } \\
\text { Depends on remaining tooth structure }\end{array}$ & $\begin{array}{c}11 \\
122 \\
255 \\
11 \\
\end{array}$ & $\begin{array}{c}2.75 \% \\
30.57 \% \\
63.90 \% \\
2.75 \%\end{array}$ \\
\hline $\begin{array}{l}\text { 2.What should be the apical } \\
\text { seal after post placement? }\end{array}$ & $\begin{array}{c}2 \mathrm{~mm} \\
3 \mathrm{~mm} \\
4-5 \mathrm{~mm} \\
\text { Depends on remaining tooth structure }\end{array}$ & $\begin{array}{c}21 \\
17 \\
353 \\
8 \\
\end{array}$ & $\begin{array}{c}5.26 \% \\
4.26 \% \\
88.47 \% \\
2 \%\end{array}$ \\
\hline $\begin{array}{l}\text { 3. What should be the diam- } \\
\text { eter of the post used? }\end{array}$ & $\begin{array}{c}\text { 1/2 Root diameter } \\
1 / 3 \text { Root diameter } \\
2 / 3 \text { Root diameter } \\
\text { Depends on remaining tooth structure }\end{array}$ & $\begin{array}{c}29 \\
255 \\
103 \\
12 \\
\end{array}$ & $\begin{array}{c}7.26 \% \\
63.90 \% \\
25.80 \% \\
3 \% \\
\end{array}$ \\
\hline $\begin{array}{l}\text { 4.Do you believe every } \\
\text { endodontically treated tooth } \\
\text { requires placement of a } \\
\text { post? }\end{array}$ & $\begin{array}{c}\text { Always } \\
\text { Depends on the remaining tooth structure } \\
\text { Never } \\
\text { Sometimes }\end{array}$ & $\begin{array}{c}48 \\
256 \\
4 \\
91 \\
\end{array}$ & $\begin{array}{c}12.03 \\
64.16 \% \\
1 \% \\
22.80 \% \\
\end{array}$ \\
\hline $\begin{array}{c}\text { 5.Do you think post rein- } \\
\text { forces endodontically treated } \\
\text { teeth and reduces fracture } \\
\text { probability? }\end{array}$ & $\begin{array}{c}\text { Always } \\
\text { Depends on remaining tooth structure } \\
\text { Never } \\
\text { Sometimes } \\
\end{array}$ & $\begin{array}{c}177 \\
166 \\
8 \\
48 \\
\end{array}$ & $\begin{array}{c}44.30 \% \\
41.60 \% \\
2 \% \\
12.03 \% \\
\end{array}$ \\
\hline $\begin{array}{l}\text { 6.Do you think the ferrule } \\
\text { effect can increase fracture } \\
\text { resistance in an endodonti- } \\
\text { cally treated teeth? }\end{array}$ & $\begin{array}{c}\text { Always } \\
\text { Depends on remaining tooth structure } \\
\text { Never } \\
\text { Sometimes } \\
\end{array}$ & $\begin{array}{c}190 \\
133 \\
3 \\
73 \\
\end{array}$ & $\begin{array}{c}47.60 \% \\
33.33 \% \\
0.75 \% \\
18.29 \% \\
\end{array}$ \\
\hline $\begin{array}{l}\text { 7.On the basis of material } \\
\text { which type of prefabricated } \\
\text { post do you prefer from a } \\
\text { longevity point of view? }\end{array}$ & $\begin{array}{l}\text { Ceramic post } \\
\text { Fiber post } \\
\text { Metal post } \\
\text { Others } \\
\end{array}$ & $\begin{array}{c}30 \\
52 \\
315 \\
2 \\
\end{array}$ & $\begin{array}{l}7.51 \% \\
13.03 \% \\
78.90 \% \\
0.50 \% \\
\end{array}$ \\
\hline $\begin{array}{l}\text { 8.On the basis of shape } \\
\text { which type of post do you } \\
\text { prefer from a retention point } \\
\text { of view? }\end{array}$ & $\begin{array}{c}\text { Depends on the canal anatomy and available dentin. } \\
\text { Parallel sided post } \\
\text { Parallel tapered post } \\
\text { Tapered post }\end{array}$ & $\begin{array}{c}148 \\
12 \\
229 \\
10\end{array}$ & $\begin{array}{l}37.09 \% \\
3 \% \\
74.90 \% \\
2.50 \% \\
\end{array}$ \\
\hline $\begin{array}{l}\text { 9. Which do you commonly } \\
\text { prefer for rinsing the canal } \\
\text { before post cementation? }\end{array}$ & $\begin{array}{c}\text { Chlorhexidine } \\
\text { EDTA } \\
\text { Saline } \\
\text { Sodium hypochlorite } \\
\end{array}$ & $\begin{array}{c}7 \\
10 \\
53 \\
329 \\
\end{array}$ & $\begin{array}{c}1.75 \% \\
2.50 \% \\
13.20 \% \\
82.45 \%\end{array}$ \\
\hline $\begin{array}{l}\text { 10.What type of cement do } \\
\text { you commonly prefer for } \\
\text { cementation of the post? }\end{array}$ & $\begin{array}{l}\text { Glass ionomer cement } \\
\text { Resin cement } \\
\text { Zinc phosphate cement. }\end{array}$ & $\begin{array}{c}13 \\
384 \\
2 \\
\end{array}$ & $\begin{array}{l}3.25 \% \\
96.20 \% \\
0.50 \% \\
\end{array}$ \\
\hline $\begin{array}{l}\text { 11. Which core material do } \\
\text { you prefer to use frequently? }\end{array}$ & $\begin{array}{c}\text { Amalgam } \\
\text { Composite } \\
\text { Glass ionomer cement } \\
\text { Others } \\
\end{array}$ & $\begin{array}{c}11 \\
355 \\
31 \\
2 \\
\end{array}$ & $\begin{array}{c}2.75 \% \\
88.90 \% \\
7.76 \% \\
0.50 \% \\
\end{array}$ \\
\hline $\begin{array}{c}\text { 12. What is the most common } \\
\text { cause of failure of ETT in } \\
\text { your practice? }\end{array}$ & $\begin{array}{c}\text { Crown fracture } \\
\text { Endodontic failure } \\
\text { No failure } \\
\text { Root fracture } \\
\end{array}$ & $\begin{array}{c}50 \\
328 \\
4 \\
17 \\
\end{array}$ & $\begin{array}{c}12.53 \% \\
82.20 \% \\
1 \% \\
4.26 \% \\
\end{array}$ \\
\hline $\begin{array}{l}\text { 13. When do you start post } \\
\text { space preparation in an ETT? }\end{array}$ & $\begin{array}{c}\text { Directly } 24 \text { after obturation } \\
\text { Immediately after root canal obturation } \\
\text { One week after obturation } \\
\text { Several weeks after obturation }\end{array}$ & $\begin{array}{c}17 \\
4 \\
258 \\
120 \\
\end{array}$ & $\begin{array}{c}4.26 \% \\
1 \% \\
64.66 \% \\
30.07 \% \\
\end{array}$ \\
\hline
\end{tabular}




\begin{tabular}{|c|c|c|c|}
\hline $\begin{array}{l}\text { 14. When using prefabri- } \\
\text { cated post which type do you } \\
\text { prefer? }\end{array}$ & $\begin{array}{l}\text { Ceramic posts } \\
\text { Fiber reinforced post } \\
\text { Metal post } \\
\text { Others } \\
\text { Always }\end{array}$ & $\begin{array}{c}23 \\
355 \\
19 \\
2 \\
5\end{array}$ & $\begin{array}{c}5.76 \% \\
88.97 \% \\
4.76 \% \\
0.50 \% \\
1.25 \%\end{array}$ \\
\hline $\begin{array}{l}\text { 15. When do you decide to } \\
\text { place an intracanal post? }\end{array}$ & $\begin{array}{l}\text { When one coronal wall/no wall is left but ferrule of } 2 \mathrm{~mm} \text { remains } \\
\qquad \text { When three coronal walls remain } \\
\text { When two coronal walls remain }\end{array}$ & $\begin{array}{c}28 \\
65 \\
301\end{array}$ & $\begin{array}{l}7.01 \% \\
16.29 \% \\
75.40 \%\end{array}$ \\
\hline $\begin{array}{l}\text { 16. What type of post do } \\
\text { you use on an ETT anterior } \\
\text { teeth? }\end{array}$ & $\begin{array}{c}\text { Cast post and core } \\
\text { Glass fibre post } \\
\text { Metal post/metal screw post } \\
\text { Zirconia post }\end{array}$ & $\begin{array}{c}11 \\
351 \\
7 \\
30 \\
\end{array}$ & $\begin{array}{c}2.75 \% \\
87.90 \% \\
1.75 \% \\
7.51 \% \\
\end{array}$ \\
\hline $\begin{array}{l}\text { 17. What type of post do you } \\
\text { use on an ETT posterior } \\
\text { teeth? }\end{array}$ & $\begin{array}{c}\text { Cast post and core } \\
\text { Glass fibre post } \\
\text { Metal post/metal screw post } \\
\text { Zirconia post }\end{array}$ & $\begin{array}{c}49 \\
15 \\
330 \\
5\end{array}$ & $\begin{array}{c}12.28 \% \\
3.75 \% \\
82.70 \% \\
1.25 \%\end{array}$ \\
\hline $\begin{array}{l}\text { 18. How often do you place a } \\
\text { crown in a tooth with a post } \\
\text { and core? }\end{array}$ & $\begin{array}{c}\text { Always } \\
\text { Depends on remaining tooth structure } \\
\text { Sometimes }\end{array}$ & $\begin{array}{c}146 \\
235 \\
18\end{array}$ & $\begin{array}{c}36.50 \% \\
58.80 \% \\
4.50 \%\end{array}$ \\
\hline $\begin{array}{l}\text { 19. Which crown material do } \\
\text { you use for ETT with post } \\
\text { and core? }\end{array}$ & $\begin{array}{c}\text { Full ceramic crown } \\
\text { Full metal crown } \\
\text { Others } \\
\text { Porcelain fused to metal crown }\end{array}$ & $\begin{array}{c}38 \\
8 \\
4 \\
349\end{array}$ & $\begin{array}{c}9.50 \% \\
2 \% \\
1 \% \\
87.40 \%\end{array}$ \\
\hline $\begin{array}{l}\text { 20.If the remaining dentin } \\
\text { thickness of an ETT is less } \\
\text { which post do you use? }\end{array}$ & $\begin{array}{c}\text { Cast post } \\
\text { Everstick post } \\
\text { Fibre reinforced post } \\
\text { Others }\end{array}$ & $\begin{array}{c}97 \\
92 \\
208 \\
2\end{array}$ & $\begin{array}{c}24.30 \% \\
23 \% \\
52.10 \% \\
0.50 \%\end{array}$ \\
\hline $\begin{array}{l}\text { 21. Are you aware of the } \\
\text { recent techniques that can be } \\
\text { used for the restoration of } \\
\text { endodontically treated teeth? }\end{array}$ & $\begin{array}{l}\text { Yes } \\
\text { No }\end{array}$ & $\begin{array}{c}359 \\
40\end{array}$ & $\begin{array}{c}89.90 \% \\
10 \%\end{array}$ \\
\hline
\end{tabular}

Figure 1. Bar chart showing association between field of practice and question as to which is the most appropriate length of the post, $\mathrm{X}$ axis represents the field of practice and $\mathrm{Y}$ axis represents the total number of responses to the question .Majority of the percentage of participants were aware of the appropriate length of the post. Chi square test (3.17) was done and association was found to be not statistically significant. Pearson's Chi square $P$ value $=0.213, p>0.05$.

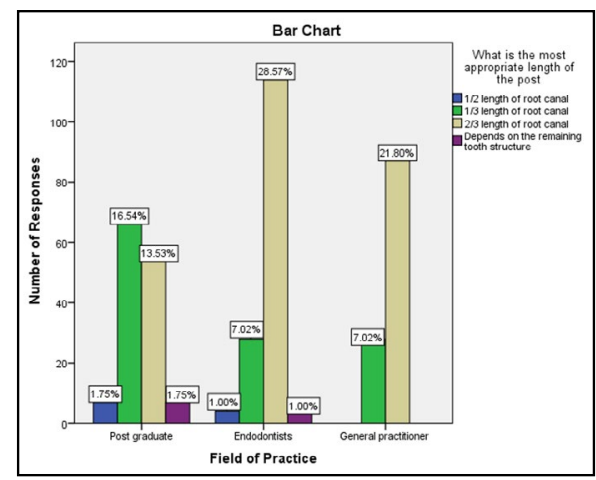

Figure 2. Bar chart showing association between field of practice and question as to which type of post is preffered in terms of retention. $X$ axis represents the field of practice and $Y$ axis represents the total number of responses to the question. Majority of the participants preferred the use of parallel tapered post length of the post in terms of retention of the post. Chi square test (2.88) was done and association was found to be statistically significant. Pearson's Chi square $\mathbf{P}$ value $=0.044, \mathrm{p}<0.05$.

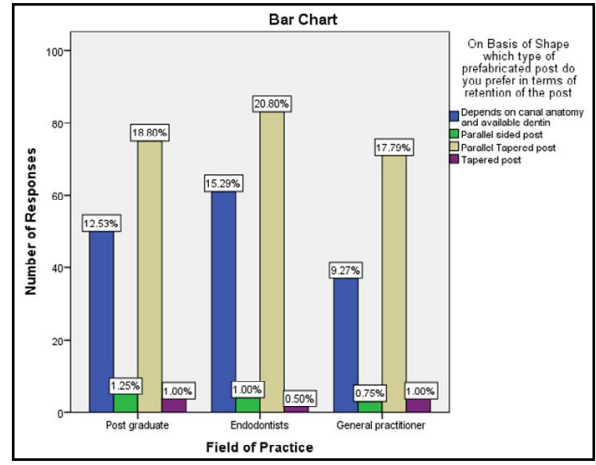


Figure 3. Bar chart showing association between field of practice and question as to on basis of material which type which post was most preferred in terms of longevity. $\mathrm{X}$ axis represents the field of practice and $\mathrm{Y}$ axis represents the total number of responses to the question. Majority of the participants preferred the use of metal posts in terms of longevity of the post. Chi square test (0.58) was done and association was found to be not statistically significant. Pearson's Chi square $\mathbf{P}$ value $=0.20, \mathrm{p}>0.05$

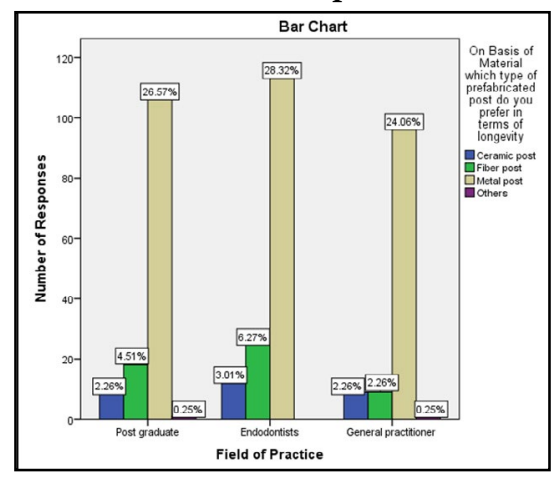

Figure 4. Bar chart showing association between field of practice and question as to what is the most common cause of failure of endodontically treated teeth. $\mathrm{X}$ axis represents the field of practice and $\mathrm{Y}$ axis represents the total number of responses to the question. Majority of the participants responded to endodontic failure accounting for the highest cause of failure of endodontically treated teeth . Chi square test (1.15) was done and association was found to be statistically significant. Pearson's Chi square $P$ value $=0.031, \mathrm{p}<0.05$.

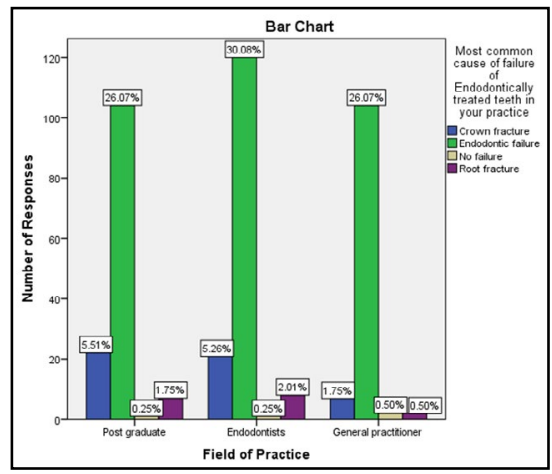

Figure 5. Bar chart showing association between field of practice and question as when is the preferred time to start post space preparation for an endodontically treated tooth. $\mathrm{X}$ axis represents the field of practice and $\mathrm{Y}$ axis represents the total number of responses to the question. Majority of the participants agreed to start post space preparation for an endodontically treated teeth one week after obturation. Chi square test (1.15) was done and association was found to be statistically significant. Pearson's Chi square $\mathbf{P}$ value $=0.031, \mathrm{p}<0.05$.

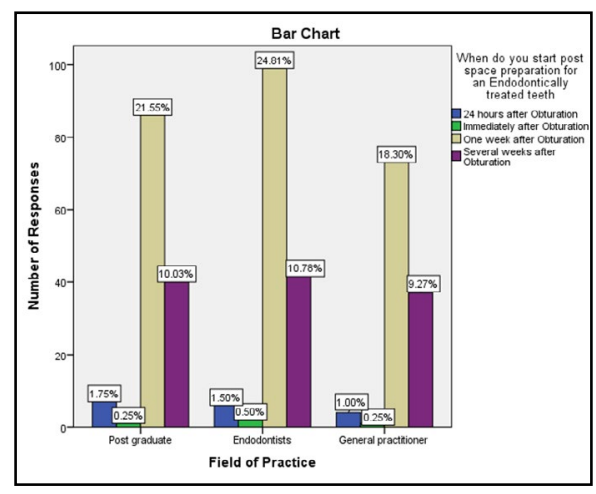

Germany and the United Kingdom which suggested every tooth does not require placement of a post [34]. Most of the participants believed that placement of a post strengthens endodontically treated teeth. The results received were similar to the findings of studies among general practitioners in Sweden, Germany, and Northern Ireland [29, 34, 35]. The placement of a post is generally suggested in restoration of endodontically treated teeth if the amount of residual tooth structure is not sufficient to support the core material [36].
Ferrule effect of 1-2 $\mathrm{mm}$ does increase the fracture resistance of teeth [37]. The ferrule effect is a key factor in avoiding clinical failures $[34,36]$. The majority of the practitioners believed the placement of a ferrule is an important feature in endodontically treated teeth. The use of prefabricated metal post was more common compared to the use of prefabricated fiber post, various guidelines for optimum post length are that the post length should be equal to $2 / 3$ of the root canal, that it should be equal to the length of the clinical crown and there should be about 4-5mm of apical seal of gutta-percha [38]. Most of the practition- 
Figure 6. Bar chart showing association between field of practice and question as to when the remaining dentin thickness of an endodontically treated tooth is less which post is preferred. $\mathrm{X}$ axis represents the field of practice and $\mathrm{Y}$ axis represents the total number of responses to the question. Majority of the participants agreed placement of fibre reinforced post when the remaining dentin thickness of an endodontically treated tooth is less.Chi square test (0.58) was done and association was found to be statistically significant.Pearson's Chi square $P$ value $=0.05, p=0.05$.

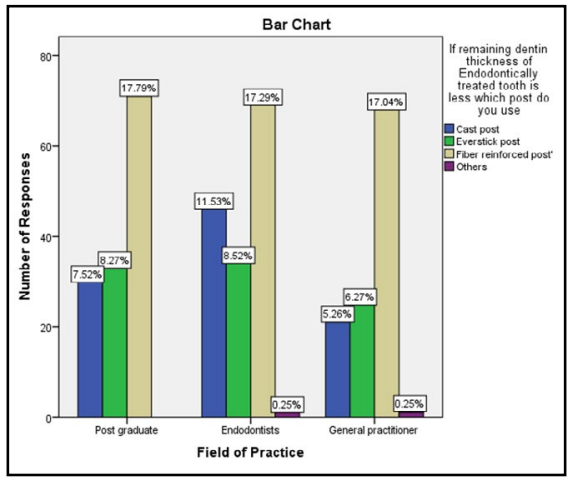

Figure 7. Bar chart showing association between field of practice and question as to which core material was used frequently for restoration of endodontically treated teeth.X axis represents the field of practice and $\mathrm{Y}$ axis represents the total number of responses to the question. Majority of the participants used composite as the core material for restoration of endodontically treated teeth.Chi square test (0.58) was done and association was found to be statistically significant. Pearson's Chi square $P$ value $=-0.72, \mathrm{p}<0.05$.

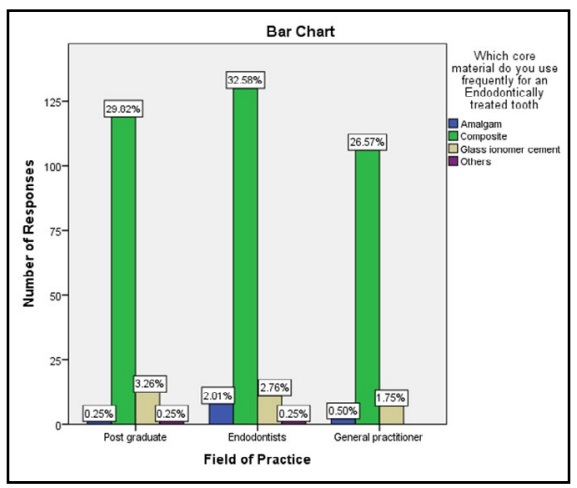

Figure 8. Bar chart showing association between field of practice and question as to which crown material was used frequently endodontically treated teeth requiring post and core. $\mathrm{X}$ axis represents the field of practice and $\mathrm{Y}$ axis represents the total number of responses to the question. Majority of the participants preferred use of porcelain fused to metal crown as the crown material for endodontically treated teeth requiring post and core.Chi square test (1.15) was done and association was found to be statistically significant. Pearson's Chi square $P$ value $=0.037, p<0.05$.

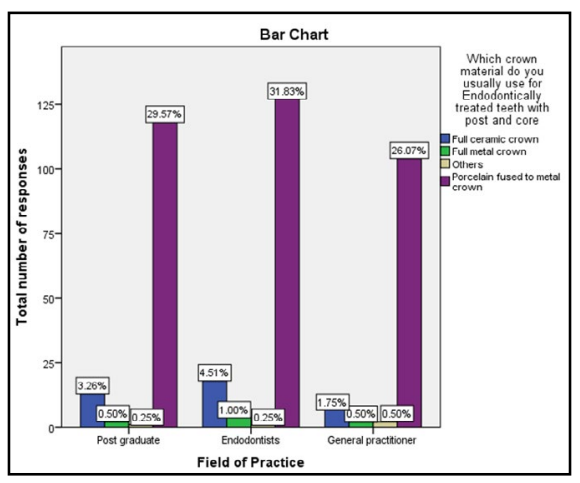

ers in the present survey considered post length as $2 / 3 \mathrm{rd}$ of the root canal [39].

The diameter of the post should be $1 / 3$ rd the root diameter. Studies have proved that as the amount of dentin removal increases, the fracture resistance of teeth decreases [40]. In the present survey majority of practitioners believed post diameter should not exceed more than $1 / 3$ rd of the root diameter. The research confirmed that post diameter creates internal stresses within the root and does not contribute to the retention of the post $[41,42]$.
Parallel tapered posts was the preferred material of choice in regards to the shape of the post by the majority of the practitioners.

The participants of the study preferred to use sodium hypochlorite as the preferred irrigant for rinsing the root canal before postplacement which was followed by saline for rinsing the root canal [4, 43-45]. Sodium hypochlorite was recommended for irrigating the root canal system because of its effective antimicrobial and tissue solving action [46]. More recently resin cement has been introduced for luting the remaining tooth structure [47, 48]. Resin- 
Figure 9. Bar chart showing association between field of practice and question as to how often a crown in endodontically treated teeth that requires post and core. $\mathrm{X}$ axis represents the field of practice and $\mathrm{Y}$ axis represents the total number of responses to the question. Majority of the participants decided for crown placement depending on the remaining tooth structure.Chi square test (5.19) was done and association was found to be statistically insignificant. Pearson's Chi square $P$ value $=0.074, \mathrm{p}>0.05$.

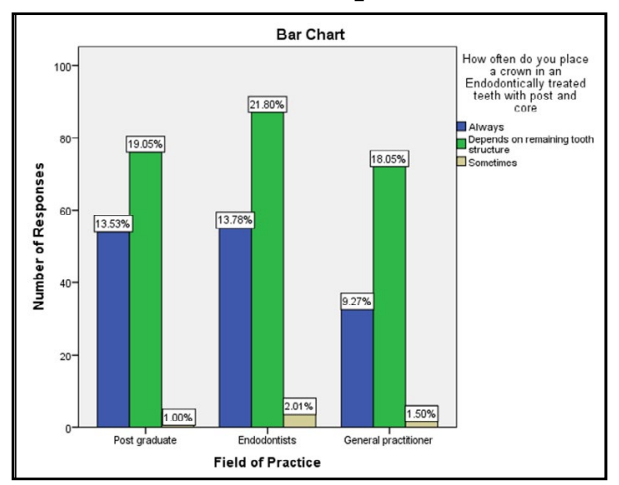

Figure 10. Bar chart showing association between field of practice and question as to whether ferrule effect increases fracture resistances in an endodontically treated tooth $\mathrm{X}$ axis represents the field of practice and $\mathrm{Y}$ axis represents the total number of responses to the question. Majority of the participants responded that the ferrule effect has an influence of increasing fracture resistance of an endodontically treated tooth.Chi square test (0.86) was done and association was found to be statistically insignificant. Pearson's Chi square $P$ value $=0.24, p>0.05$.

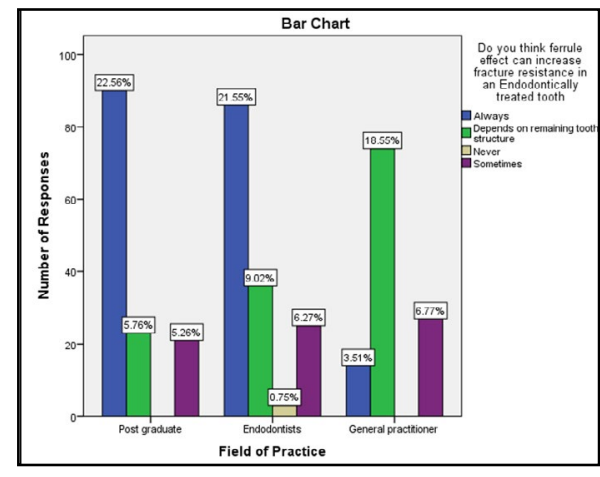

based luting cements are reported to have higher bond strengths and significantly increased post retention, as well as it helps to strengthen the endodontically-treated tooth in comparison with other conventional types of cement and glass-ionomer cement [49].

The most frequently used core material used was composite resin followed by glass ionomer and amalgam by the participants of the study. Amalgam, when used as a core material, can cause aesthetic problems with all ceramic crowns and sometimes make the gingiva look dark. There is also risk of tattooing the cervical gingiva with amalgam particles during the crown preparation. Amalgam has no natural adhesive properties and taking into account the potential concern of mercury toxicity, it is no longer widely used as a buildup material. The participants of this study preferred to use composite resin as it adheres to tooth structure, can be prepared and finished immediately, has good color under all-ceramic crowns and has an aesthetically acceptable appearance.

In the current study, endodontic failure was considered the most common reason for the failure of endodontically treated teeth by the majority of the participants followed by crown fracture. In one study in Germany, the loss of retention was considered the reason for the failure of endodontically treated teeth while in another study the endodontic failure was considered the most common reason for the failure of endodontically treated teeth among the participants of the study [50]. A recent literature re- view on clinical studies of fiber posts reported that the use of fiber-reinforced composite posts out-perform metal posts in the restoration of endodontically treated teeth. The evidence cannot be considered as conclusive. Under conditions of extensive coronal destruction the placement of a fiber-reinforced composite post would seem to protect the tooth against failure, however the most common type of failure with fiber-reinforced composite posts is debonding [51].

The use of cast posts may result in a significantly greater loss of tooth structure compared to fiber posts, and their use should be limited to cases in which no additional dentine has to be removed to allow for their cementation [52]. When two or more walls are missing in a tooth after caries excavation and endodontic obturation, placement of a dowel or post is indicated for retention of the core foundation and final coronal restoration [53]. The majority of the participants agreed to place an intracanal post when two coronal walls were remaining while the rest of the participants agreed to place an intracanal post when three walls were remaining. Considering the time of post space preparation majority of the practitioners agreed preparation of post space in teeth requiring post within one week following obturation while some of the practitioners agreed post space preparation within several weeks following obturation of endodontically treated teeth. When only one to two walls of dentin remain, for both anterior and posterior teeth either an adhesively cemented prefabricated metal or fiber post with a composite resin core buildup foundation can be used. 
Fiber posts can be used when there is minimal radicular tooth structure because they offer approximately the same modulus of elasticity as dentin and forces would be distributed more evenly in the shorter root, resulting in fewer root fractures [54]. Majority of participants preferred the placement of fiber posts in the anterior teeth and metal posts in the posterior teeth.

Two systematic reviews examined the outcome of endodontically treated teeth when restored using direct restorations versus crowns [55-56]. One systematic review concluded that endodontically treated teeth restored without crown coverage had a lower long-term survival rate in comparison with teeth covered with crowns [55]. The other concluded that there is currently a lack of well-founded evidence to determine whether restoring a premolar with ample coronal tooth structure restored with composite resin restoration is more effective than a crown [56]. Majority of the practitioners placed a full ceramic crown as restoration of choice for endodontically treated teeth with post and core. When the remaining dentin thickness was less, the majority of the participants preferred the use of fiber reinforced post and remaining participants preferred the use metal post followed by everstick post.

Everstick post is a flexible, resin impregnated, uncured glass fiber post which has an interpenetrating polymer network (IPN) resin matrix that can be cured to the anatomic shape of the crown [57]. After curing these fiber-reinforced posts exhibit high tensile strength and elastic modulus similar to elasticity of dentin thereby causing less root fracture and stresses to be evenly distributed [58].

\section{Clinical Significance}

While planning restoration of an endodontically treated teeth effort should be made to preserve the coronal and radicular dentin, to avoid contamination of the root canal system, to restore the tooth immediately after root canal treatment if possible and to use posts only when necessary to retain a core buildup. During selection and placement of post principles to the following include adequate length, resistance form, strength to allow preservation of dentin and an adequate ferrule of $2 \mathrm{~mm}$.

\section{Limitations}

This study was confined among a smaller number of population, and have not focused on recent techniques used for restoration of endodontically treated teeth.

\section{Future Scope}

This study can be conducted in a larger population. The questions can be focused on prognosis, management and longevity of endodontically treated teeth in future studies.

\section{Conclusion}

Within the limitations of this study,this cross sectional descriptive study shows a thorough knowledge and awareness among the endodontic specialists about restoration of endodontically treated teeth and its management and inadequate knowledge among general dentists. Therefore, establishing awareness among general dentists regarding restoration of endodontically treated teeth and its management is mandatory.

\section{Author Contributions}

Draft Preparation, Data collection, statistical analysis was done by Swathi UB.Reviewing, corrections done by Sindhu Ramesh and Pradeep S.

\section{Acknowledgement}

With Sincere gratitude,we acknowledge the staff members of the department of Conservative Dentistry and Endodontics, Saveetha Dental College and study participants for their extended support towards the completion of research.

\section{References}

[1]. Heydecke G, Butz F, Hussein A, Strub JR. Fracture strength after dynamic loading of endodontically treated teeth restored with different post-andcore systems. J Prosthet Dent. 2002 Apr;87(4):438-45.Pubmed PMID: 12011861.

[2]. Morgano SM, Rodrigues AHC, Sabrosa CE . Restoration of endodontically treated teeth. Dent Clin North Am.2004; 48: vi, 397-416.

[3]. Siddique R, Nivedhitha MS. Effectiveness of rotary and reciprocating systems on microbial reduction: A systematic review. J Conserv Dent. 2019 Mar-Apr;22(2):114-122.Pubmed PMID: 31142978.

[4]. Govindaraju L, Neelakantan P, Gutmann JL. Effect of root canal irrigating solutions on the compressive strength of tricalcium silicate cements. Clin Oral Investig. 2017 Mar;21(2):567-571.Pubmed PMID: 27469101.

[5]. Reeh ES, Messer HH, Douglas WH. Reduction in tooth stiffness as a result of endodontic and restorative procedures. J Endod. 1989 Nov;15(11):512-6. Pubmed PMID: 2639947.

[6]. Khandelwal A, Palanivelu A. Correlation between dental caries and salivary albumin in adult population in Chennai: An in vivo study. Braz. Dent. Sci. 2019 Apr 30;22(2):228-33.

[7]. Poorni S, Srinivasan MR, Nivedhitha MS. Probiotic Streptococcus strains in caries prevention: A systematic review. J Conserv Dent. 2019 Mar;22(2):123128.

[8]. Ramarao S, Sathyanarayanan U. CRA Grid - A preliminary development and calibration of a paper-based objectivization of caries risk assessment in undergraduate dental education. J Conserv Dent. 2019 Mar-Apr;22(2):185-190. Pubmed PMID: 31142991.

[9]. Morgano SM. Restoration of pulpless teeth: application of traditional principles in present and future contexts. J Prosthet Dent. 1996 Apr;75(4):375-80. Pubmed PMID: 8642522.

[10]. Safavi KE, Dowden WE, Langeland K. Influence of delayed coronal permanent restoration on endodontic prognosis. Endod Dent Traumatol. 1987 Aug;3(4):187-91.Pubmed PMID: 3481569.

[11]. Alsamadani KH, Abdaziz el-SM, Gad el-S. Influence of different restorative techniques on the strength of endodontically treated weakened roots. Int J Dent. 2012;2012:343712.Pubmed PMID: 22666251.

[12]. Bergman B, Lundquist P, Sjögren U, Sundquist G. Restorative and endodontic results after treatment with cast posts and cores. J Prosthet Dent. 1989 Jan;61(1):10-5.Pubmed PMID: 2644413.

[13]. Naumann M, Blankenstein F, Kiessling S, Dietrich T. Risk factors for failure of glass fiber-reinforced composite post restorations: a prospective observational clinical study. Eur J Oral Sci. 2005 Dec;113(6):519-24.Pubmed PMID: 16324143.

[14]. Azeem RA, Sureshbabu NM. Clinical performance of direct versus indirect composite restorations in posterior teeth: A systematic review. J Conserv Dent. 2018 Jan-Feb;21(1):2-9.Pubmed PMID: 29628639.

[15]. enarthanan S, Subbarao C. Comparative evaluation of the efficacy of diclofenac sodium administered using different delivery routes in the management of endodontic pain: A randomized controlled clinical trial. J Conserv Dent. 2018 May-Jun;21(3):297-301.Pubmed PMID: 29899633.

[16]. Nandakumar M, Nasim I. Comparative evaluation of grape seed and cranberry extracts in preventing enamel erosion: An optical emission spectrometric analysis. J Conserv Dent. 2018 Sep-Oct;21(5):516-520.Pubmed PMID: 30294113.

[17]. Malli Sureshbabu N, Selvarasu K, V JK, Nandakumar M, Selvam D. Concentrated Growth Factors as an Ingenious Biomaterial in Regeneration of Bony Defects after Periapical Surgery: A Report of Two Cases. Case Rep Dent. 2019 Jan 22;2019:7046203.Pubmed PMID: 30805222. 
[18]. Teja KV, Ramesh S, Priya V. Regulation of matrix metalloproteinase-3 gene expression in inflammation: A molecular study. J. Conserv. Dent. 2018 Nov;21(6):592-596.

[19]. Rajakeerthi R, Nivedhitha MS. Natural Product as the Storage medium for an avulsed tooth-A Systematic Review. Cumhur. Dent. J. 2019;22(2):24956.

[20]. Rajendran R, Kunjusankaran RN, Sandhya R, Anilkumar A, Santhosh R, Patil SR. Comparative evaluation of remineralizing potential of a paste containing bioactive glass and a topical cream containing casein phosphopeptide-amorphous calcium phosphate: An in vitro study. Pesqui. Bras. Odontopediatria Clín. Integr. 2019;19:1-10.

[21]. Vârlan C, Dimitriu B, Vârlan V, Bodnar D, Suciu I. Current opinions concerning the restoration of endodontically treated teeth: basic principles. J Med Life. 2009 Apr-Jun;2(2):165-72.Pubmed PMID: 20108535.

[22]. Nagasiri R, Chitmongkolsuk S. Long-term survival of endodontically treated molars without crown coverage: a retrospective cohort study. J Prosthet Dent. 2005 Feb;93(2):164-70.Pubmed PMID: 15674228.

[23]. Colman HL. Restoration of endodontically treated teeth.Dent Clin North Am. 1979; 23: 647-662.

[24]. Schwartz RS, Robbins JW. Post placement and restoration of endodontically treated teeth: a literature review. J. Endod. 2004 May 1;30(5):289-301.

[25]. Ross RS, Nicholls JI, Harrington GW. A comparison of strains generated during placement of five endodontic posts. J Endod. 1991 Sep;17(9):450-6. Pubmed PMID: 1811040.

[26]. Assif D, Gorfil C. Biomechanical considerations in restoring endodontically treated teeth. J Prosthet Dent. 1994 Jun;71(6):565-7.Pubmed PMID: 8040817.

[27]. Tikku AP, Chandra A, Bharti R. Are full cast crowns mandatory after endodontic treatment in posterior teeth? J Conserv Dent. 2010 Oct;13(4):246-8. Pubmed PMID: 21217953.

[28]. Whitworth JM, Walls AW, Wassell RW. Crowns and extra-coronal restorations: endodontic considerations: the pulp, the root-treated tooth and the crown. Br Dent J. 2002 Mar 23;192(6):315-20, 323-7.Pubmed PMID: 15552070 .

[29]. Eckerbom M, Magnusson T. Restoring endodontically treated teeth: a survey of current opinions among board-certified prosthodontists and general dental practitioners in Sweden. Int J Prosthodont. 2001 May-Jun;14(3):245-9. Pubmed PMID: 11484572.

[30]. Scurria MS, Shugars DA, Hayden WJ, Felton DA. GENERAL DENTISTS'PATTERNS OF RESTORING: ENDODONTICALLY TREATED TEETH. The J Am Dent Assoc. 1995 Jun 1;126(6):775-9.

[31]. Auswin MK, Ramesh S. Knowledge, attitude, and practice survey on the use of dental operating microscope in endodontics: A cross-sectional survey. Pharm. Educ. Res. 2017;7(3):320-322.

[32]. Manohar MP, Sharma S. A survey of the knowledge, attitude, and awareness about the principal choice of intracanal medicaments among the general dental practitioners and nonendodontic specialists. Indian J Dent Res. 2018 Nov-Dec;29(6):716-720.Pubmed PMID: 30588997.

[33]. Janani K, Sandhya R. A survey on skills for cone beam computed tomography interpretation among endodontists for endodontic treatment procedure. Indian J Dent Res. 2019 Nov-Dec;30(6):834-838.Pubmed PMID: 31939356.

[34]. Naumann M, Kiessling S, Seemann R. Treatment concepts for restoration of endodontically treated teeth: A nationwide survey of dentists in Germany. J Prosthet Dent. 2006 Nov;96(5):332-8.Pubmed PMID: 17098496.

[35]. Hussey DL, Killough SA. A survey of general dental practitioners' approach to the restoration of root-filled teeth. Int Endod J. 1995 Mar;28(2):91-4. Pubmed PMID: 7665207.

[36]. Morgano SM, Hashem AF, Fotoohi K, Rose L. A nationwide survey of contemporary philosophies and techniques of restoring endodontically treated teeth. J Prosthet Dent. 1994 Sep;72(3):259-67.Pubmed PMID: 7965899.

[37]. Stankiewicz N, Wilson PR. The ferrule effect: a literature review. Int. Endod. J. 2002 Jul;35(7):575-81.

[38]. Sorensen JA, Martinoff JT. Intracoronal reinforcement and coronal coverage: a study of endodontically treated teeth. J Prosthet Dent. 1984 Jun;51(6):780-
4.Pubmed PMID: 6376780.

[39]. Martin N, Jedynakiewicz N. A radiographic survey of endodontic post lengths [abstract 418]. J Dent Res. 1989;68(Special Issue):919.

[40]. Deutsch AS, Musikant BL, Cavallari J, Silverstein L, Lepley J, Ohlen K, et al. Root fracture during insertion of prefabricated posts related to root size. J Prosthet Dent. 1985 Jun;53(6):786-9.Pubmed PMID: 3891978.

[41]. Ruemping DR, Lund MR, Schnell RJ. Retention of dowels subjected to tensile and torsional forces. J Prosthet Dent. 1979 Feb;41(2):159-62.Pubmed PMID: 366115

[42]. Mattison GD, von Fraunhofer JA. Angulation loading effects on cast-gold endodontic posts: a photoelastic stress analysis. J Prosthet Dent. 1983 May;49(5):636-8.Pubmed PMID: 6343592.

[43]. Bitter K, Hambarayan A, Neumann K, Blunck U, Sterzenbach G. Various irrigation protocols for final rinse to improve bond strengths of fiber posts inside the root canal. Eur J Oral Sci. 2013 Aug;121(4):349-54.Pubmed PMID: 23841787

[44]. Siddique R, Sureshbabu NM, Somasundaram J, Jacob B, Selvam D. Qualitative and quantitative analysis of precipitate formation following interaction of chlorhexidine with sodium hypochlorite, neem, and tulsi. J Conserv Dent. 2019 Jan-Feb;22(1):40-47.Pubmed PMID: 30820081.

[45]. Siddique R, Nivedhitha MS, Jacob B. Quantitative analysis for detection of toxic elements in various irrigants, their combination (precipitate), and para-chloroaniline: An inductively coupled plasma mass spectrometry study. J Conserv Dent. 2019 Jul-Aug;22(4):344-350.Pubmed PMID: 31802817.

[46]. Teja KV, Ramesh S. Shape optimal and clean more. Saudi Endod. J. 2019 Sep 1;9(3):235.

[47]. Seow LL, Toh CG, Wilson NH. A survey of current practices among general dental practitioners in Manchester in 2002. Prim Dent Care. 2003 Jul;10(3):87-92.Pubmed PMID: 12929337.

[48]. Saupe WA, Gluskin AH, Radke RA Jr. A comparative study of fracture resistance between morphologic dowel and cores and a resin-reinforced dowel system in the intraradicular restoration of structurally compromised roots. Quintessence Int. 1996 Jul;27(7):483-91.Pubmed PMID: 8941826.

[49]. Sen D, Poyrazoglu E, Tuncelli B. The retentive effects of pre-fabricated posts by luting cements. J Oral Rehabil. 2004 Jun;31(6):585-9.Pubmed PMID: 15189317.

[50]. Mendoza DB, Eakle WS, Kahl EA, Ho R. Root reinforcement with a resinbonded preformed post. J Prosthet Dent. 1997 Jul 1;78(1):10-4.

[51]. Cagidiaco MC, Goracci C, Garcia-Godoy F, Ferrari M. Clinical studies of fiber posts: a literature review. Int J Prosthodont. 2008 Jul 1;21(4):328-336.

[52]. Ikram OH, Patel S, Sauro S, Mannocci F. Micro-computed tomography of tooth tissue volume changes following endodontic procedures and post space preparation. Int Endod J. 2009 Dec;42(12):1071-6.Pubmed PMID: 19912377.

[53]. Smidt A, Venezia E. Techniques for immediate core buildup of endodontically treated teeth. Quintessence Int. 2003 Apr;34(4):258-68.Pubmed PMID: 12731611

[54]. Faria AC, Rodrigues RC, de Almeida Antunes RP, de Mattos Mda G, Ribeiro RF. Endodontically treated teeth: characteristics and considerations to restore them. J Prosthodont Res. 2011 Apr;55(2):69-74.Pubmed PMID: 20709618.

[55]. Stavropoulou AF, Koidis PT. A systematic review of single crowns on endodontically treated teeth. J Dent. 2007 Oct 1;35(10):761-7.

[56]. Fedorowicz Z, Carter B, de Souza RF, Chaves CD, Nasser M, Sequeira-Byron P. Single crowns versus conventional fillings for the restoration of root filled teeth. Cochrane Database Syst Rev. 2012;(5):CD009109.

[57]. Fokkinga WA, Le Bell AM, Kreulen CM, Lassila LV, Vallittu PK, Creugers $\mathrm{NH}$. Ex vivo fracture resistance of direct resin composite complete crowns with and without posts on maxillary premolars. Int Endod J. 2005 Apr;38(4):230-7.Pubmed PMID: 15810973.

[58]. Ferrari M, Vichi A, Grandini S, Goracci C. Efficacy of a self-curing adhesiveresin cement system on luting glass-fiber posts into root canals: an SEM investigation. Int J Prosthodont. 2001 Nov-Dec;14(6):543-9.Pubmed PMID: 12066701 . 